\title{
Evolution of the Sahelian Coastal Water Table Under the Influence of Anti-salt Dam, in Salt Leaching Process
}

\author{
Bama Nati Aïssata Delphine ${ }^{1}$, Bado Boubié Vincent ${ }^{2}$, Soussou Sambou ${ }^{3}$, Faye Serigne ${ }^{4}$, \\ Lompo François ${ }^{1}$, Gaye Cheikh Becaye ${ }^{4}$ \\ ${ }^{1}$ Institute of Environment and Agricultural Research, Ouagadougou, Burkina Faso \\ ${ }^{2}$ Africa Rice, Saint-Louis, Senegal \\ ${ }^{3}$ Hydraulic Laboratory, University Cheikh Anta Diop, Dakar, Senegal \\ ${ }^{4}$ Hydrogeology Laboratory, University Cheikh Anta Diop, Dakar, Senegal
}

Email address:

nati_aissata@yahoo.fr (B. N. A. Delphine)

\section{To cite this article:}

Bama Nati Aïssata Delphine, Bado Boubié Vincent, Soussou Sambou, Faye Serigne, Lompo François, Gaye Cheikh Becaye. Evolution of the Sahelian Coastal Water Table Under the Influence of Anti-salt Dam, in Salt Leaching Process. Journal of Water Resources and Ocean Science. Vol. 5, No. 6, 2016, pp. 104-107. doi: 10.11648/j.wros.20160506.14

Received: November 4, 2016; Accepted: November 25, 2016; Published: January 3, 2017

\begin{abstract}
In the sahelian coastal areas, most lowlands are threatened nowadays by the risk of salinization due to climate change. Given the scale of this soil's degradation, several actions have been undertaken including anti-salt dam. Therefore, the objective of this work was to understand the impact of these dams on the fluctuation of ground water during wet season. The study has been conducted in 2011, in two lowlands, in the Sine Saloum area, in Senegal. Thirty piezometers have been installed in each lowland, in order to follow the evolution of the water table. The dynamics of this water table during the year is strongly correlated with rainfall, evapotranspiration, runoff, infiltration and standing water in the reservoir. We noticed that the salt leaching process by anti-salt dam strongly affects the process of infiltration and discharge of the water table.
\end{abstract}

Keywords: Water Table, Rain, Lowland, Anti-salt-Dam, Groundwater's Evolution

\section{Introduction}

In coastal areas, most of the lowlands are threatened nowadays by the risk of salinization $[1,2,3]$. More than 830 millions hectares of land in arid and semi-arid area have been degraded by salt $[4,5]$. In Senegal, the low pluviometry in Sine Saloum area $[6,7]$ has reduced the volume of fresh water that drains from the watershed in to rivers, and thus, saltwater from the ocean intrudes much farther in the land [8]. This intrusion of seawater has increased salinization of land $[9,10]$, surface water [11] and ground water [12]. Given the scale of this soil's degradation, several actions have been undertaken, including anti-salt dams $[13,14]$. So, the objective of this work was to understand the impact of these dams on the fluctuation of ground water during wet season.

\section{Material and Method}

\subsection{Presentation of Study Area}

The total area of the lowland of Ndour Ndour is 134 ha, 60 ha affected by salt, 35 ha threatened by salt and 39 ha of good valuable soils in front end of the Valley [15]. It's watershed is $16.6 \mathrm{~km}^{2}$ and is located at $14^{\circ} 05^{\prime} 46^{\prime \prime} \mathrm{N} 16^{\circ} 18^{\prime} 31 \mathrm{~W}$. Ndinderling is located at $13^{\circ} 39^{\prime} 43^{\prime \prime} \mathrm{N} 16^{\circ} 23^{\prime} 23^{\prime \prime} \mathrm{W}$. It's total area is 974 ha. The climate of this area is Sudano-Sahelian, that is characterized by the alternation of two seasons: a dry season of eight months, from mid-October to mid-June, with a cool period from November to January and arainy season of four months, from mid-June to mid-October. The average rainfalls are 588 $\mathrm{mm}$ at Ndour Ndour and $800 \mathrm{~mm}$ at Ndinderling. Evaporation is very important, around $2950 \mathrm{~mm} /$ year. The average monthly temperatures varies from $24^{\circ} \mathrm{C}$ (in January) to $31^{\circ} \mathrm{C}$ (May). Three winds treams are important in the 
region: the maritime trade wind, the continental winds (Harmattan) and Monsoons. At Ndour Ndour, there life is flat [15], water table is shallow and salty [16] and soils are generally sandy, sandy loam or clay loam acidic or weakly acidic [17]. However in Ndinderling, the relief is composed by four units [18].

\subsection{Description of the Anti-salt Dam in the Lowlands}

An anti-salt dam is a structure of water retention made in the valley of Sine Saloum to prevent the invasion of land by sea water and to protect and recover saline soils upstream of the structure. It includes a dike and evacuator regulated by a valve. The anti-salt dams of Ndour Ndour and Ndinderling have been built in 2001 and 2010 in packed clay.

\subsection{Monitoring of Groundwater}

Thirty piezometers have been installed in each lowland during 2011 wet season. Surveys of ground water level have been performed once every week.

\section{Results and Discussion}

\subsection{Different Water Flow Generated by the Anti-salt Dam}

By accumulation of runoff fin the basin and then making periodic drainage, we act on the flows at the level of dam. During the dry season, at the downstream of the dam, sea water is accumulated. Apart of this salt water flows below the dam, and by capillary action, rise from the soil through layer sand its evaporation lead to accumulation of salt on soil surface upstream of dam (Figure 1). During the rainy season, rain water dissolves these salts to red upstream. In fact, when the valve remains closed, it allows runoff to accumulate in the basin. Part of the retained water infiltrates and contributes to ground water recharging. Salt accumulated in the soil dissolves in standing water. The valve is then opened to allow drainage of salt water (Figure 1).

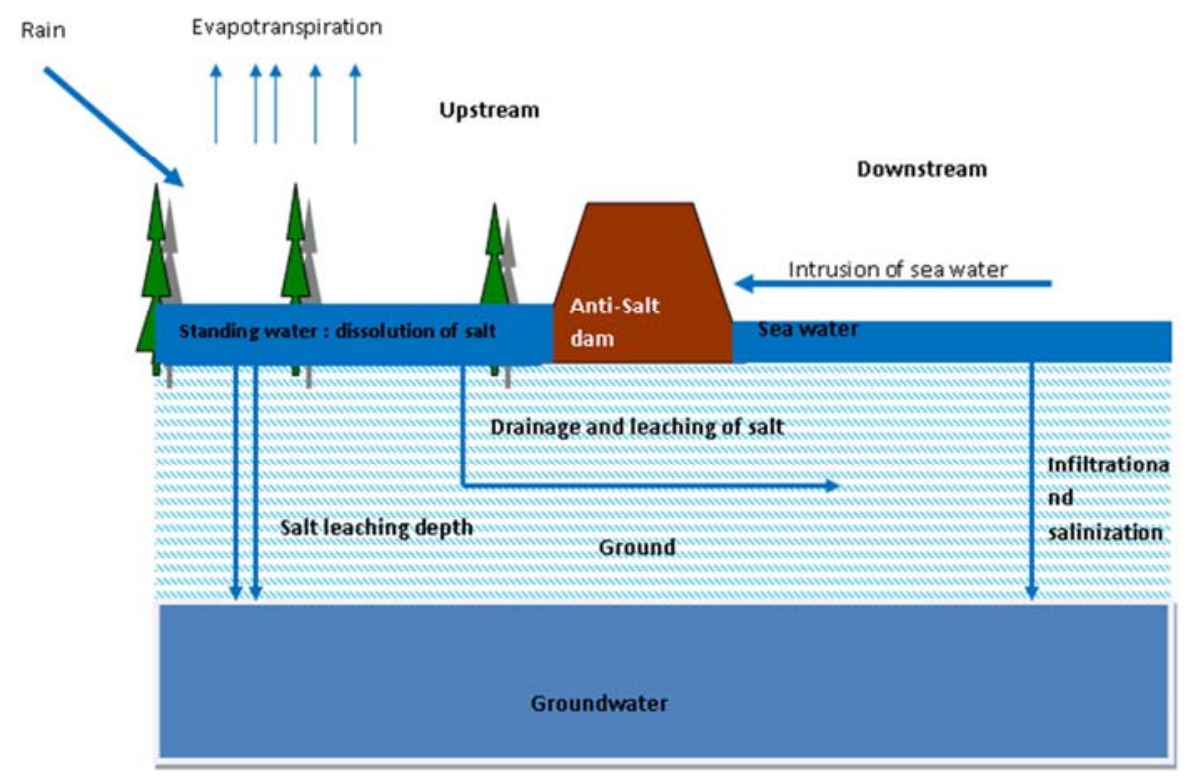

Figure 1. Different water flow generated by the anti-salt dam when there is the standing water upstream.

\subsection{Fluctuation of the Water Table Induced by the Anti-salt Dam}

\section{Ndour Ndour}

The $120 \mathrm{~mm}$ (Figure 2) of rain have permitted the leaching of accumulated salt on surface of soil. (Figure 3) below: at the date of $20^{\text {th }}$ July, the ground water level was less than 50 $\mathrm{cm}$, the rain didn't permit to recharge much ground water. From $25^{\text {th }}$ July to $5^{\text {th }}$ August, the important rains allowed aground water recharge. Between $5^{\text {th }}$ and $20^{\text {th }}$ August, the periodic droughts have resulted in the great capillary rise which resulted in a decrease of ground water table. The evaporation of salt water allowed salt outcrop on surface of soil at this moment. The standing water at the beginning of September allowed dilution of the salt accumulated on the surface. From early September until October, the water table has under gone several fluctuations. Sometimes we have the standing water, sometimes the ground was dry. In addition, during the 2011 season, the different points of exploration of the ground water have allowed to identify two trends of fluctuation depending on the dyke (Figure 3 and 4 Ndour Ndour).

\section{Ndinderling}

The high rainfall received before $25^{\text {th }}$ July (Figure 2) has allowed salt leaching. On $25^{\text {th }}$ July, the ground water level was less than $50 \mathrm{~cm}$ (3and 4). From $10^{\text {th }}$ August we have the standing water. Here too, there were the oscillations of the water table according to the rain. But starting from $10^{\text {th }}$ August, with the closing of valve, we have the permanent standing water (Figure 3 and 4). In addition, we have two trends of evolution at the ground water level. The portion of the water table located upstream but near to the dike is charging continuously. While the water table located upstream but more than $30 \mathrm{~m}$ of the dam has a discharge at the end of the rainy season. 


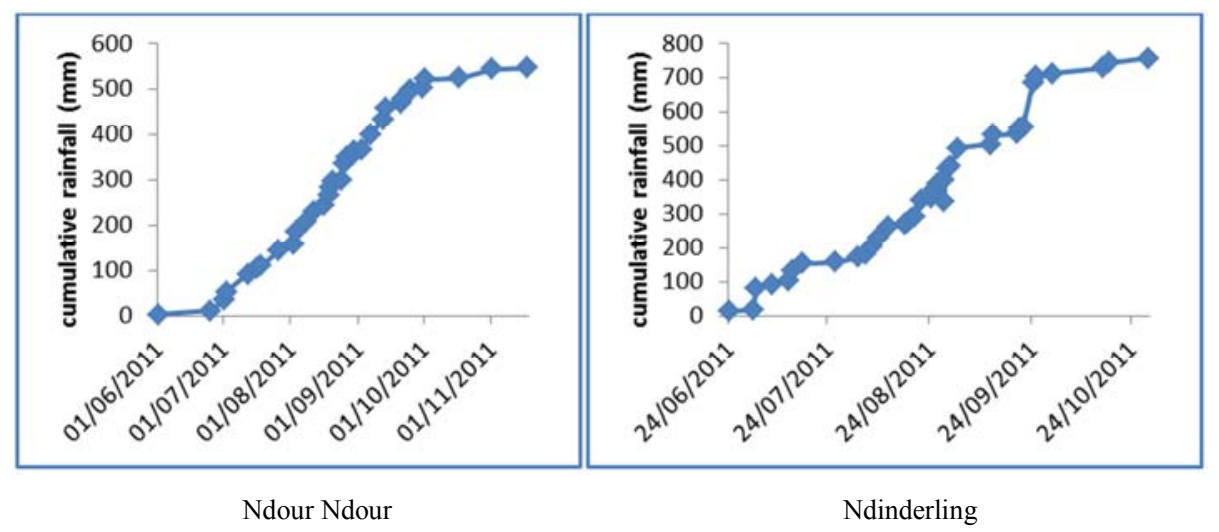

Figure 2. Cumulative rainfall in Ndour Ndour and Ndinderling during the rainy season 2011.

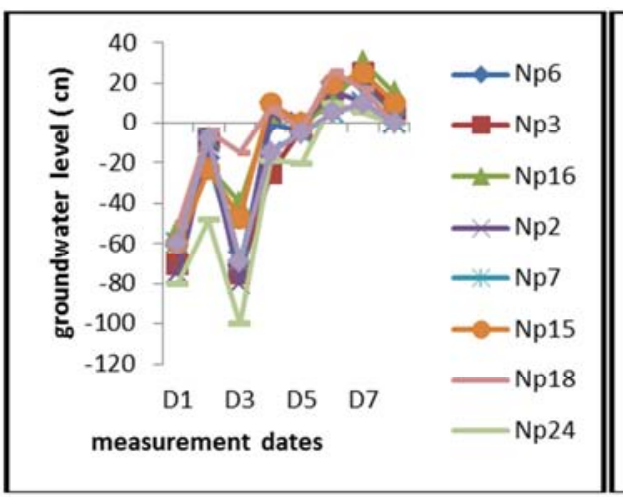

Ndour Ndour

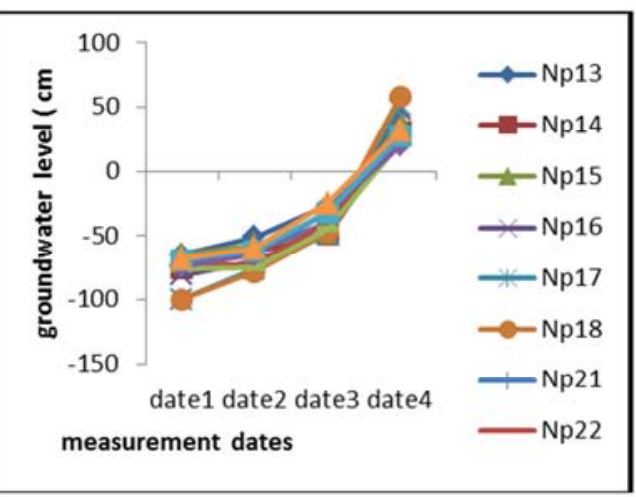

Ndinderling

Figure 3. Variation of the water table located near of the dam during wet season 2011.

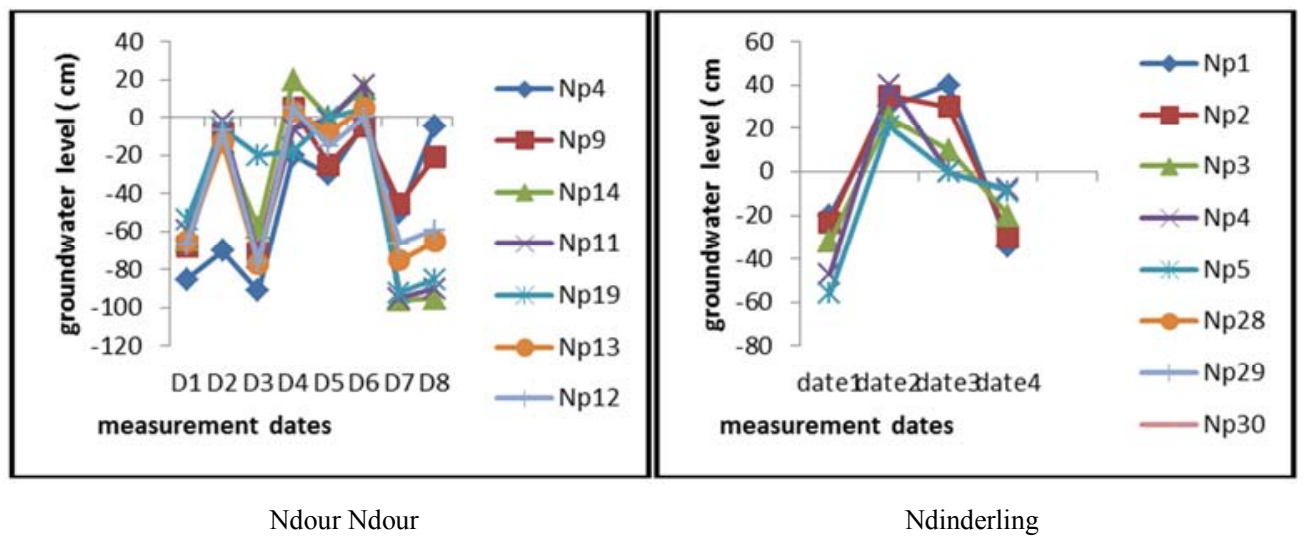

Figure 4. Variation of the water table located far from the dam during wet season 2011.

The fluctuation of these water tables during wet season is strongly correlated with rainfall, evapotranspiration, runoff, infiltration and thickness of unsaturated soil $[19,9,20]$ led to the same conclusion. The lack of standing water at Ndour Ndour and the profile of water table near the dam are linked to the process of salt leaching which has not allowed a continuous recharge of the aquifer at Ndour Ndour unlike Ndinderling where the valve remained closed. However, at Ndinderling, there is much loss of water by hypodermic flow under the dam. This water loss by percolation has been highlighted by [21]. In these lowlands, dams are essential in the fight against drought and salinity [22]. Furthermore, in the lowland like Ndinderling where rainfall is high, the dam allows good management of standing water.

\section{Conclusion}

The fluctuation of these water tables during wet season is strongly correlated with climate of the area and soil structure. The leaching of salt process affects strongly the recharge of the water table. In these lowlands, dams are essential in the fight against drought and salinity and allows good management of standing water. 


\section{References}

[1] GOPALAKRISHNANG., NEGRIM. C., WANGM., WUM., SNYDERS. Et MITCHELLR., 2008. Use of marginal land and water to maximize bio fuel production. In "Bio fuels, bio energy, and bio products from sustainable agricultural and forest crops: Proceedings of the short rotation crops international conferencepp19-20; Bloomington, Department of Agriculture, Forest Service, Northern Research Station, Newtown Square, PA.

[2] HAMECK D. A., ELLSWORTHJ. W., HOPKINSB. G., SULLIVAND. M. et STEVENSR. G., 2007. Managing SaltAffected Soils for Crop Production. A Pacific Northwest Extension Publication, 24pp.

[3] BOUTKHIL M., HABIB. M., HAMOUDIA., 2007. Contraintes et perspectives des aménagements hydro-agricoles et antiérosifs en Algérie. Actes des Journées Scientifiques Inter-Réseaux de l'A.U.F., Hanoi.

[4] Martinez-Beltran, J., Manzur, C. L., 2005. Overview of salinity problems in the world and FAO strategies to address the problem. In: Proceedings of the international salinity forum, Riverside, California, pp. 311-313.

[5] CORBISHLEYJ. Et PEARCED., 2007. Growing trees on saltaffected land. ACIAR Impact Assessment Series Report No. 51, ACIAR, July 2007.

[6] BISILLIAT J. et FENETRIEUTORD M., 1984. Les villes en Afrique: Leurs rôles et leur fonction dans le développement national et régional, Le Sénégal. pp. 140.

[7] MARIUSC., 1995. Effets de la sécheresse sur l'évolution des mangroves du Sénégal et de la Gambie. Sécheresse 6:123-125.

[8] DIOUFP.S., 1996. Les peuplements de poissons des milieux estuariens de l'Afrique de l'Ouest: l'exemple de l'estuaire hyper salin du Sine-Saloum. Thèse de Doctorat, Université de Montpellier II, 267p.

[9] CAMARA M., KEBE M., Miézan K. M., 2007. Caractérisation agronomique, économique et biophysique du continuum bas-fond: cas des complexes sahéliens et soudanosahéliens du Sine-Saloum au Sénégal. Sciences et Nature vol. $4 \mathrm{n}^{\circ} 1: 1-15$.

[10] DIAI. M. M., 2003. Elaboration et mise en œuvre d'un plan de gestion intégrée (la réserve de biosphère du delta du Saloum, Sénégal). UICN, Gland, Suisse et Cambridge, RoyaumeUni.xiv+130pp.

[11] NIASSE M., AFOUDA A., AMANI A., 2004. Réduire la vulnérabilité de l'Afrique de l'ouest aux impacts du climat sur les ressources en eau, les zones humides et la désertification, éléments de stratégie régionale de préparation et d'adaptation. Union Mondiale pour la Nature (UICN), 82p.
[12] FAYE S., NIANG DIOPI., CISSE FAYES., EVANS D.G., PFISTER M., MALOSZEWSKI P. et SEILERK.P., 2001. Sea water intrusion in the Dakar (Senegal) confined aquifer: calibration and testing of a 3D finite element model. In: Seiler K. P. and Wohnlich S. (eds), New Appproaches Characterizing Groundwater Flow. Proceedings of the XXXII A H Congress, Munich, 1014 Sept 2001", A. A. Balkema, Lisse / Abingdon, 2, 1183-1186.

[13] DUMAS D., MIETTON M., HAMERLYNCK O., PESNEAUD F., KANE A., COLY A., DUVAIL S. et BABA M. L. O., 2010. Large Dams and Uncertainties: The Case of the Senegal River (West Africa). Society and Natural Resources, 23: 11, 1108-1122, First published on: 12 August 2010.

[14] SMEDEMA L. K., ABDEL-DAYEM S. et OCHS W., 2000. Drainage and agricultural development. Irrigation and Drainage System 14, 223-235.

[15] MBODJ S., 2007. Une meilleure valorisation des bas-fonds du Sine Saloum par la GIRE. SIWI, RANDOLL, GTZ.

[16] MBOD JS., 2001. Étude d'impact environnemental et méthodologie de construction des ouvrages anti-sel ou de retenue dans le contexte PAGERNA. Kaolack, Sénégal Rapport Technique, p75.

[17] CAMARA M., KEBE M., MIEZAN M. K., 2008. Intensification de la riziculture de bas-fonds dans le SineSaloum, Sénégal. Cahiers Agricultures vol.17pp451-455.

[18] C. T. R. S (Cartographie et télédétection des ressources du Sénégal), 1986. Etude de la géologie, de l'hydrogéologie, des sols, de la végétation et des potentiels d'utilisation des sols (SDSU-RSI-86-01).

[19] BAMA NATI A. D., BADO B. V., SOUSSOU S., MEL V., GAYE C. B., 2013. Anti-salt dam as a means of recovering lowland degraded by sea water: the Case of lowland Ndour Ndour, Senegal. American Journal of Environmental Protection, vol. 2, $\mathrm{n}^{\circ}$. 3, pp. 79-84. doi: 10.11648/j.ajep.20130203.12.

[20] DIOP N. F., MALOU R., DACOSTA H., MENDY A., 2002. Contrainte climatique des nappes d'eau souterraines en zones soudano-sahéliennes: cas de la nappe phréatique du bassin de la Néma dans la région du Sine au centre-ouest du Sénégal. African journal of science and technology (AJST). Science and engineering 3(1), pp 44-50.

[21] JANSSEN M., LENNARTZ B., 2008. Characterization of preferential flow path ways through paddy bunds with dye tracer tests. Soil Science Society of America Journal. 72 p. $1756-1766$.

[22] BOONRAT J., GRIENGGRAI P., SHUF., KENF., 2006. Improving drought to lerance in rainfed lowland rice: an example from Thailand. Elsevier, Agricultural Water Management 80, 225-240. 